ROMAN WŁODEK ${ }^{*}$

Instytut Historii im. Tadeusza Manteuffla Polskiej Akademii Nauk

Zakład Polskiego Słownika Biograficznego, Kraków

\title{
Joseph Green, producent polskich filmów jidyszowych
}

\begin{abstract}
Aвstract. Włodek Roman, Joseph Green, producent polskich filmów jidyszowych [Joseph Green, producer of Polish Yiddish-language films]. „Images” vol. XXVI, no 35. Poznań 2019. Adam Mickiewicz University Press. Pp. 77-101. ISSN 1731-450X. DOI 10.14746/i.2019.35.04.

Joseph Green (1900-1996), born Josef Chaim Grinberg in Łódź, was one of the most important producers of films in Yiddish. At the beginning of the sound era in the United States, he worked on dubbing in Yiddish for Jewish films, including Joseph in the Land of Egypt. He received a copy of the film as a royalty, which he then used with great success. The money helped him produce four Jewish films in Poland between 1936 and 1938: Yiddle with His Fiddle, The Jester, Little Mother and A Letter to Mother. Green left Poland in the spring of 1939. When the world of Shtetls - evoked by him - disappeared as a result of the Second World War, he ceased making films.
\end{abstract}

KEYwORs: Joseph Green, faryidisht film, Yiddish film, Molly Picon, Leon Trystan

W latach trzydziestych XX wieku około trzech milionów obywateli Polski posługiwało się językiem jidysz. Warszawę, która była drugim (po Nowym Jorku) największym skupiskiem ludności żydowskiej na świecie, zamieszkiwało ponad trzysta pięćdziesiąt tysięcy Żydów. Kwitło żydowskie życie kulturalne: wydawano około trzystu tytułów prasowych, ukazywały się liczne publikacje książkowe, malarze podejmowali próby stworzenia własnego, wyrazistego narodowego stylu w sztuce. Działały różnorodne zespoły teatralne, od rewiowych po dramatyczne. Już przed I wojną światową zaczęto w Warszawie realizować filmy jidyszowe, ale dynamiczny rozwój ich produkcji nastąpił dopiero w drugiej połowie lat trzydziestych, gdy powstało ich dziewięć. Cztery wyprodukował przybyły z Ameryki aktor i reżyser Joseph Green.

Joseph Green urodził się w Łodzi jako Josef/Josif Chaim Grinberg/Grünberg. Według obowiązującego w zaborze rosyjskim kalendarza juliańskiego przyszedł na świat 10 kwietnia 1900 roku[1], według kalendarza gregoriańskiego - 23 kwietnia. Jego rodzicami byli: pochodzący z Lublina Wigdor Judka Grinberg (ur. 1865) i Estera (Etla) z Hammerów (ur. 1862) z leżącego pod Łodzią Rzgowa. Grinbergowie początkowo mieszkali prawdopodobnie przy ulicy Piotrkowskiej 25 w Łodzi. Mieli pięcioro dzieci. Najstarsza córka, Giena Jenta (ur. 1889),

* Za życzliwą pomoc w zgromadzeniu materiału podziękowania zechcą przyjąć: Ylain Mayer, Maureen Mroczek Morris i Tomasz Magierski.

[1] Podstawowe dane metrykalne na podstawie: Akta miasta Łodzi, księgi ludności stałej z lat 1903-1931,
Images vol. XXVI/no. 35

Poznań 2019

ISSN 1731-45OX 
w 1907 roku wyszła za mąż za Chila Rzeszkowskiego i zamieszkała z nim w Ozorkowie. Druga z kolei, Szifra (ur. 1896), w 1918 roku została żoną Szyi Hersza (Ilii) Grynberga; oboje pozostali w Łodzi i z czasem przejęli sklep Wigdora Judki przy ulicy Magistrackiej 19 (obecnie Aleksandra Kamińskiego)[2]. Po Jencie urodził się Josef i młodsi od niego Ruchla (ur. 1903) oraz Abram (1910-1919).

Wigdor Judka Grinberg był drobnym kupcem handlującym garderobą. Wolne wieczory chętnie spędzał w teatrze z Josefem. Wspólnie oglądali przedstawienia, głównie żydowskie, ale także polskie i niemieckie. Teatr żydowski w Łodzi miał już pewną tradycję. Powstał w 1905 roku dzięki Icchokowi Zandbergowi i był drugim, po lwowskim, stałym zespołem jidyszowym na ziemiach polskich. Zandberg wynajmował Teatr Wielki, znajdujący się przy ulicy Konstantynowskiej 14 (obecnie Legionów). Sala widowiskowa, mogąca pomieścić aż 1250 widzów, była zwykle wypełniona - Łódź zamieszkiwało wtedy około 150 tysięcy Żydów. W repertuarze dominowały operetki, znane z niemieckich tytułów: Die brillante Dame z muzyką Georga, Die jüdische Krone Borysa Tomaszewskiego (Borisa Thomashefsky'ego) - zwanego ojcem teatru żydowskiego w Ameryce, oraz König Ahaswer i Sulamit Abrahama Goldfadena. Wystawiano także melodramaty, między innymi Damę kameliowa Aleksandra Dumasa syna, oraz dramaty: Medeę Jakowa Gordina (a zapewne i inne jego sztuki) oraz Żywego trupa Lwa Tołstoja, a także tragedie: między innymi Daniela Danieli Richarda Vossa. W roku 1913 i 1914 w Teatrze Wielkim występowali gościnnie najwybitniejsi żydowscy aktorzy epoki, między innymi Ester Rachel Kamińska, David Kessler i Borys Tomaszewski. Po śmierci Zandberga dyrekcję teatru w grudniu 1915 roku objął Morris Wachsman i kierował nim przez kilka lat. Od końca 1913 roku pod kierownictwem Juliusza Adlera i Hermana Sierockiego działał w Łodzi drugi teatr jidyszowy, Scala, mieszczący się przy ulicy Cegielnianej 18 (obecnie Więckowskiego 15), prezentujący głównie repertuar operetkowy, ale także dramaty Gordina[3].

Josef Grinberg uczył się zarówno w chederze, jak i, od końca 1914 roku, w polskiej szkole średniej. Częste wizyty w teatrze wpłynęły na jego wybory życiowe. Od lata 1914 roku występował w amatorskim teatrze żydowskim, a w 1915 na jakimś kursie zaczął się uczyć aktorstwa. Prawdopodobnie po śmierci ojca, która nastąpiła 5 listopada 1917 roku (został pochowany na cmentarzu przy ulicy Brackiej), Josef przeniósł się do Warszawy. Miał tam jeszcze większe możliwości oglądania występów teatrów jidyszowych. Zapewne wtedy zetknął się z zespołem znanym jako Trupa Wileńska (Wilner Trupe), który rozpoczął dzia-

[2] Informator m. Łodzi z Kalendarzem na rok 1920. Spis firm handlowo-przemysłowych $w$ Łodzi z podziałem na branże w porządku alfabetycznym, Łódź [1920], s. 95. „Drobną sprzedaż garderoby”, zarejestrowaną na Wigdora Judkę Grinberga, prowadzono od roku 1922 przy ulicy Nowo-Zarzewskiej 32 (obecnie
Zarzewska). Zob. Podręczny rejestr handlowy, Łódź [1926], s. 126 (pozycja 8831).

[3] Zob. M. Leyko, Teatr Icchoka Zandberga, [w:] Łódzkie sceny żydowskie. Studia i materiały, pod red. M. Leyko, Łódź 20oo, s. 39-44. 
łalność 18 lutego 1916 roku, wystawiając w lokalu pocyrkowym przy placu Łukiskim w Wilnie trzyaktową komedią Rodak (Der landsman), napisaną przez Szaloma Asza pięć lat wcześniej. Zanim w październiku 1917 roku Trupa Wileńska osiadła w Warszawie, gościła między innymi w Kownie i Białymstoku, stopniowo zdobywając uznanie. W Warszawie występowała w teatrze Elizeum przy ulicy Karowej 18.

W 1918 roku, aby udoskonalić umiejętności aktorskie, Grinberg przeniósł się do Berlina, który za sprawą działającego tam Maxa Reinhardta i dynamicznie rozwijającego się ekspresjonizmu był najważniejszym na świecie centrum teatralnym. Od września 1921 roku, jako Jüdisches Künstlertheater, występowała tam Trupa Wileńska[4]. Przy Kommandanenstrasse 57 pokazała między innymi swoją najsłynniejszą inscenizację - Dybuka (Dibek) Szymona An-skiego (prapremiera w reżyserii Dawida Hermana odbyła się 9 grudnia 1920 roku w Elizeum). Wileńczycy w repertuarze mieli też między innymi Pustą karczmę (Di puste kreczme) Pereca Hirszbejna, Rodzinę/Rozsiani i rozrzuceni (Cezejt un ceszprejt) Szolem Alejchema oraz Dzień i noc (Tog un nacht) An-skiego[5]. Właśnie w Berlinie Grinberg związał się z Trupą Wileńską, która $\mathrm{z}$ amatorskiego zespołu w ciągu kilku lat stała się sławnym teatrem jidyszowym podziwianym w całej Europie, nie tylko przez Żydów. W 1923 roku zespół dotarł do Londynu. W nieistniejącym już dziś Pavilion Theatre przy Whitechapel Road w październiku 1923 roku aktorzy wileńscy wystawili Boga zemsty (Der Got fun nekome) Asza. Bohaterem sztuki, uważanej przez żydów ortodoksyjnych za bluźnierczą, a prowokacyjną przez innych odbiorców, jest Jankiel Czapczowicz, który dorobił się majątku, prowadząc dom rozpusty; aby odkupić swoje winy, funduje Torę. Na użytek Lord Chamberlain's Office, czyli oficjalnej cenzury, w angielskojęzycznym streszczeniu Czapczowicza przedstawiono jako szefa kabaretu, a prostytutki jako artystki - i Wileńczycy otrzymali pozwolenie na występy. Prasa jednak dostrzegła, że te zmiany nie zostały wprowadzone do inscenizacji i Boga zemsty zdjęto $\mathrm{z}$ afisza.

Londyńskie spektakle Wilnian podziwiał Harry Thomashefsky, który prowadził w Nowym Jorku (wraz z ojcem Borysem i Williamem Rollandem) Thomashefsky Broadway Yiddish Theatre (44th Street, West Broadway), i zaprosił ich na występy. Drugiego stycznia 1924 roku Grinberg wraz z kolegami z zespołu: Jakobem Bleiferem, Mosesem Federem, Matusem Kowalskim, Jakobem Lubockim i Chaimem Szneurem wypłynął z Southampton statkiem „Majestic”. Do Nowego Jorku dotarł 10 stycznia. Niecałe trzy tygodnie później, 29 stycznia, zespół rozpoczął występy pokazem Dybuka, w którym Grinberg grał Menaszego i Henocha; w lutym wystawiono Zielone pola (Grine felder) Hirszbejna.

\section{Współpraca z Wileńczykami}

[4] H. Riss, Żydowscy artyści z Polski w Berlinie, przeł. M. Leyko, [w:] Teatr żydowski w Polsce, pod red. A. Kuligowskiej-Korzeniewskiej, M. Leyko, Łódź 1998, s. 349-353.
[5] D. Caplan, Nomadic Chutzpah: The Vilna Troupe's Transnational Yiddish Theatre Paradigm, 1915-1935, „Theatre Survey” 2014, z. 3, s. 311. 
Następnie Grinberg związał się z Unzer Theater i 29 stycznia 1925 roku zagrał tam rolę Sąsiada w sztuce Dawida Pińskiego Bilans końcowy (Der lecter sachakl), reżyserowanej przez Egona Brechera. Po roku przeszedł do zespołu Rudolpha Schildkrauta, którego mógł podziwiać w Berlinie, a zetknął się z nim zapewne w zespole Thomashefsky'ego, i w lutym 1926 roku grał w jego teatrze (Schildkraut Theatre) w Bronksie w Joszke muzykant (Joszke musikant) Osipa Dymowa.

Hollywoodzki epizod

W Jidiszer

Kunst-Teater

Maurice'a Schwartza
W 1926 roku Rudolph Schildkraut i jego syn Joseph zostali zaangażowani do monumentalnego hollywoodzkiego filmu o tematyce biblijnej Król królów (The King of Kings) w reżyserii Cecila B. DeMille’a. Rudolph do roli Kajfasza, a Joseph - Judasza. Grinberg, który wyjechał z nimi, także wziął udział w tym widowisku. Statystował też w dwóch scenach Śpiewaka jazzbandu (The Jazz Singer) Alana Croslanda, którego premiera (6 października 1927) otworzyła epokę dźwięku w kinie światowym. Producenci filmu, bracia Sam i Jack Warnerowie, w trakcie realizacji porozumiewali się z większością ekipy w jidysz. Dla Grinberga był to pierwszy impuls prowadzący go do decyzji, aby w przyszłości realizować filmy w tym właśnie języku[6]. Choć zdjęcia z jego udziałem zajęły tylko dwa dni, spędził na planie aż dziewięć tygodni, poznając podstawy techniki filmu dźwiękowego. Istotny dla niego mógł być także problem podjęty w Śpiewaku jazzbandu. W filmie główny bohater staje przed dylematem, czy w Jom Kippur zaśpiewać Kol nidre w synagodze, jak sobie tego życzył jego umierający ojciec, czy też wystąpić w premierze na Broadwayu, która stwarzała mu możliwość zrobienia kariery. Podobnych rozstrzygnięć, choć nie w tak skrajnej formie, musiało dokonać wielu Żydów. Często były one tematem sztuk i filmów: czy trwać w tradycji, czy korzystać z możliwości, jakie przynosi nowa rzeczywistość, bowiem zachowanie równowagi pomiędzy życiem religijnym i świeckim $\mathrm{w}$ dynamicznie zmieniającym się świecie, jeśli w ogóle było możliwe, to na pewno niełatwe.

Po powrocie z Hollywood do Nowego Jorku Grinberg związał się z Jidiszer Kunst-Teater, kierowanym przez Maurice’a Schwartza, i początkowo pełnił w jego przedsiębiorstwie bardzo ważną funkcję agenta prasowego. Występował też, głównie w rolach drugoplanowych, między innymi w reżyserii Schwartza, jako Szlojme w Kidusz ha-Szem według Szaloma Asza, Motl w Bóg, człowiek i szatan (God, mencz un tejwl) Jakowa Gordina, Bernard Hard w Major Noah (Mayor Noyekh) Harry'ego Sacklera, a ponadto między innymi Harry w Łachmanach (Szmates) Halperna Lejwika w reżyserii Abrama Morewskiego, Student w Wiśniowym sadzie Antona Czechowa w reżyserii Leo Bulgakova[7]
[6] E.A. Goldman, Visions, Images, and Dreams. Yiddish Film Past and Present, Ann Arbor 1983, s. 89; J. Hoberman, Bridge of Light. Yiddish Film Between Two Worlds, Hanover, London 2010, s. 236 i 254.
[7] Urodzony w Moskwie jako Leo Bułhakow aktor i reżyser amerykański; w 1943 roku zagrał generała Golza (Waltera) w filmie Komu bije dzwon (For Whom the Bell Tolls) wyreżyserowanym przez Sama Wooda według powieści Ernesta Hemingwaya. 
i Roderig w Otellu Williama Shakespeare’a w reżyserii Borisa S. Glagolina. Kolejne role zagrał już jako Green, bowiem 3 października 1929 roku otrzymał obywatelstwo amerykańskie i zmienił nazwisko[8]. Wystąpił wtedy między innymi w reżyserowanych przez Schwartza przedstawieniach: Żyd Süss według Liona Feuchtwangera - w roli sekretarza tytułowego bohatera, a w Bładzacych gwiazdach (Blondżende sztern) Alejchema zagrał Młodego Lejbela oraz Mr Clummera. W sumie w latach 1928-1930 w Jidiszer Kunst-Teater wystąpił w kilkunastu rolach.

Po nastaniu dźwięku w kinie widzowie żydowscy długo czekali na chwilę, w której z ekranu przemówi do nich ktoś w ich języku. Producenci, z powodu wysokich kosztów sprzętu dźwiękowego, nie mogli sobie pozwolić na realizacje w jidysz. Wyszukiwali natomiast zrealizowane w Stanach Zjednoczonych, Polsce, Austrii, Niemczech i Rosji filmy z pierwszoplanowym wątkiem żydowskim i poddawali je przeróbkom. Pierwotna przynależność, narodowa bądź gatunkowa, w której film wcześniej funkcjonował, traciła znaczenie. W wyniku działań, które pod względem technicznym przypominają strategię subwersywną: przemontowanie pierwotnej wersji, dodanie narracji, prologu, epilogu, kwestii poszczególnych bohaterów, muzyki oraz piosenek, powstawał inny film. Ta nowa, zrekontekstualizowana wersja wchodziła w nowy paradygmat - dźwiękowe kino żydowskie.

Na początku czerwca 1932 roku w Nowym Jorku odbyła się premiera trwającej osiemdziesiąt minut opowieści Józef $w$ Egipcie (Josef in Micraim). Na podstawie amerykańskiego filmu biblijnego Józef w ziemi egipskiej (Joseph in the Land of Egypt) z 1914 roku (reż. Eugene Moore) [9] stworzył go George Roland, emigrant z Rosji (ur. 1882), jak się miało okazać, największy specjalista w jidyszyzacji. Producenci tej nowej wersji - Samuel Goldstein i Mortimer D. Sikawitt - utrzymywali jednak, że ich dzieło jest oryginalne, zrealizowane w plenerach Egiptu z aktorami teatru żydowskiego[10]. Green jako honorarium za zdubbingowanie partii Józefa otrzymał kopię Józefa w Egipcie. Gdy wyjechał na występy teatralne w Toronto, zabrał film ze sobą i wprowadził do eksploatacji. W rozmowie z Judith N. Goldberg, przeprowadzonej w 1976 roku, Green wspominał: „W ciągu pierwszego tygodnia zarobiłem na filmie więcej niż w ciągu roku w teatrze" [11]. Zrezygnował wtedy z przedstawień i przeniósł się do Montrealu, gdzie Józef $w$ Egipcie, wyświetlany od 1 października 1932 roku, czyli od Rosz ha-Szana, już po tygodniu przyniósł Greenowi cztery tysiące dolarów (w teatrze pracował za 150

[8] Tak imię, jak i nazwisko jest bardzo popularne i często wywołuje pomyłki: Joseph Green, bohater niniejszego tekstu, pomylony z konserwatorem z Muzeum Wojska w Warszawie, jest uważany za konsultanta Pana Tadeusza (1928) Ryszarda Ordyńskiego; mylony jest także z aktorem występującym w westernach.

[9] Zob. The American Film Institute Catalog. Within our Gates: Ethnicity in American Feature
Jidyszyzacja
Films, 1911-1960, red. A. Gevinson, Berkeley 1997, s. 536; J.N. Goldberg (Laughter through Tears. The Yiddish Cinema, Rutherford, Madison, Teaneck, London, Toronto 1983, s. 67) i E.A. Goldman (op.cit., s. 7o) uważają, że podstawę stanowił jakiś włoski film biblijny.

[10] J.N. Goldberg, op.cit., s. 67.

[11] Ibidem. 
dolarów tygodniowo)[12]. W sumie w Kanadzie zarobił około 250 tysięcy dolarów [13].

W marcu 1933 roku odbyła się premiera filmu Żydowska córka (Jidisze tochter), który Roland stworzył na podstawie niemieckiego dramatu Judith Trachtenberg, wyreżyserowanego w 1920 roku przez Henrika Galeena[14] na podstawie prozy Karla Emila Franzosa. Jest to opowieść o Judycie, Żydówce, która, zaślepiona miłością do hrabiego Agenora Baranowskiego, przyjmuje chrzest i bierze ślub kościelny, nie wiedząc, że został on zaaranżowany jak przedstawienie teatralne przez zakochanego w niej, ale słabego człowieka. Po odkryciu podstępu bohaterka odnosi zwycięstwo moralne, doprowadzając do ślubu cywilnego, po czym popełnia samobójstwo. Inskrypcja na jej grobie głosi: „Judyta, hrabina Baranowska". Green był narratorem tego filmu.

Dystrybucja: Green-Film
Aktorzy kabaretów i teatrów żydowskich z Ameryki często przyjeżdżali do Starego Kraju, łącząc występy, cieszące się na ogół dużym uznaniem, z podróżami sentymentalnymi. W 1932 roku występowało we Lwowie małżeństwo Rose Wallerstein i Oscar Ostroff[15]. Powrócili latem 1933 roku w towarzystwie Sama (Israela) Gertlera, komediopisarza, a zarazem aktora[16], oraz Greena, który był reklamowany jako Józef Grün, „znakomity artysta największych teatrów obydwu kontynentów”[17]. Czy był „znakomity”, to kwestia uznaniowa, natomiast prawdą jest, że w czasie trwającej zaledwie kilkanaście lat kariery scenicznej współpracował z najlepszymi teatrami jidyszowymi
[12] J. Hoberman, op.cit., s. 237.

[13] M. Freedland, Joseph Green. Yiddisher poppa, „The Guardian” (London), nr z czwartku 4 lipca 1996, S. 15 .

[14] Henrik Galeen, właśc. Henryk Józef Wiesenberg, urodził się 7 stycznia 1881 roku w Stryju. W latach 1895-1901, jako Wiesenberg, występował w Teatrze Towarzystwa Miłośników Sceny we Lwowie (także w objeździe) i grał (w 1901 roku) między innymi Gospodarza i Rycerza Czarnego w Weselu Stanisława Wyspiańskiego w reżyserii Jana Nowackiego i Tadeusza Pilarskiego. Na scenie lwowskiego Teatru Miejskiego debiutował 30 maja 1901 roku, grając w zastępstwie chorego Stanisława Hierowskiego Czarnego Rycerza w Weselu w reżyserii Ludwika Solskiego. Pod pseudonimem Henryk Mariewski zagrał tamże 2 września - w miejsce Solskiego Gospodarza; rolę tę powtórzył jeszcze dwukrotnie. Ok. 1903 roku w Berlinie wstąpił (początkowo jako Mariewski) do Deutsches Theater Maxa Reinhardta, uczył się także w przyteatralnej szkole i asystował Reinhardtowi; następnie reżyserował i występował w teatrach w Szwajcarii oraz Niemiec. W 1910 związał się z kinematografią. Był sekretarzem i asystentem Hannsa Heinza Ewersa, który przyśpieszył jego karierę filmową. Galeen współtworzył kino ekspresjonistyczne jako reżyser, między innymi Golema (wraz z Paulem Wegenerem, Der Golem, 1914, był także autorem scenariusza) i Studenta $z$ Pragi (Der Student von Prag, 1926), Alraune (napisał także scenariusz wg Ewersa, 1928), oraz scenarzysta, między innymi Nosferatu (1922) Friedricha Wilhelma Murnaua i Gabinetu figur woskowych (Das Wachsfigurenkabinett, 1924) Paula Leniego. Wraz z Johnem Gottowtem prowadził przez pewien czas wspomniany teatr berliński przy Kommandanenstrasse 57. W 1933 roku emigrował z Trzeciej Rzeszy. Zmarł w 1949 roku w USA. Zob. M. Szydłowska, Ze Lwowa w filmowy świat, „Przegląd Polski” (Nowy Jork) z 3 grudnia 2010, s. 6.

[15] Zob. M. Szydłowska, Z dziejów żydowskich widowisk rozrywkowych we Lwowie przed 1945, „Pamiętnik Teatralny" 2014, z. 1-2, s. 95. Ostroff urodził się w Kiszyniowie.

[16] Urodził się w 1896 roku w Skale koło Zbaraża. W 1932 debiutował w filmie jidyszowym Wuj Moses (Onkl Moses) Sidneya M. Goldina i Aubreya Scotto, nakręconym w Stanach Zjednoczonych wg powieści Asza.

[17] „Chwila” 1933, nr 5134, s. 14 (sobota, 8 lipca 1933). 
epoki. We Lwowie na scenie pawilonu letniego Teatru Żydowskiego przy ulicy Jagiellońskiej 11 (obecnie Hnatiuka) Green występował od 1 lipca 1933 roku w sztukach: Przyrodnia siostra, Tajemnicza kobieta, „arcydziele scenicznym” Podziękowanie za dziecko (Der dank far kinder), "którego premiera przeszła z niebywałym wprost powodzeniem”[18], a następnie w Nieprawej żonie (Dos umgezecleche wajb), Duszach na sprzedaż (Neszomes cu farkojfn) Williama Siegela, Wiecznej narzeczonej, Duszy kobiety oraz Najpiękniejszym dziewczęciu, komedii muzycznej A. Liliena. Zapewne i pozostałe sztuki należały do tego gatunku. Z powodu niskiego poziomu należały do szundu, czyli szmiry, produkcji najniższej jakości, które dominowały na scenach żydowskich. Ostatni raz Green zagrał we Lwowie 20 sierpnia 1933 roku w Podziękowaniu za dziecko i był to chyba ostatni występ sceniczny w jego życiu.

Green przywiózł ze sobą do Polski Józefa w Egipcie. Po zakończeniu występów we Lwowie udał się do Warszawy, gdzie zarejestrował firmę „Green-Films, New York” i przystąpił do eksploatowania kopii. „Monumentalny film biblijny 100\% mówiony i śpiewany w języku żydowskim, dramat o silnej emocji”[19],

odtwarzający tragedię sprzedaży Józefa. Główne role: najwybitniejsi artyści żydowskich teatrów w Nowym Jorku! Ponadto bierze udział w tym arcydziele 5000 statystów. Największa i najciekawsza sensacja ostatniej doby. Film jaki zdarza się oglądać raz w życiu!... Film dla dorosłych i młodzieży[20],

został pokazany pierwszy raz 4 października 1933 roku, w przeddzień święta Sukkot, w znajdującym się w dzielnicy żydowskiej kinie Fama przy ulicy Przejazd 9[21]. Green wspominał:

Pewnej nocy podczas projekcji zagadnął mnie jakiś człowiek, czy mam negatyw i uświadomił mi, że jeśli jedyna moja kopia ulegnie zniszczeniu, wylecę z interesu. I tej samej nocy ten człowiek, który dysponował odpowiednim laboratorium, sporządził negatyw. Na rano miałem gotową drugą kopię[22].

Tym życzliwym nieznajomym był inżynier Zygmunt Englemer albo jego wspólnik Stefan Fałęcki. Przy ulicy Jasnej 24 od 1932 roku prowadzili oni spółkę z ograniczoną odpowiedzialnością Komisfilm[23], zajmującą się między innymi przeprowadzaniem formalności celnych, ekspedycyjnych i cenzuralnych, opracowywaniem filmów zagranicznych oraz ich przechowywaniem[24]. „Green-Films, New York” podpisał z Komisfilmem umowę (do końca swej działalności w Polsce Green będzie działał pod tym samym, co Komisfilm, adresem) i wspólnie eksploatowali Józefa w Egipcie.

[18] „Chwila” 1933, nr 5135, s. 16 (niedziela, 9 lipca 1933).

[19] „Chwila” 1934, nr 5347, s. 2 (sobota, 10 lutego 1934).

[20] „Express Wieczorny Ilustrowany” 1933, nr 327, s. 6 (piątek, 24 listopada 1933).
[21] Ulica Przejazd obecnie nie istnieje, na miejscu kamienicy oznaczonej niegdyś numerem 9 znajduje się kino Muranów.

[22] Za: J.N. Goldberg, op.cit., s. 68.

[23] K., Komisfilm - Jasna 24, „Wiem Wszystko” 1937, nr 8, s. 6.

[24] „Wiadomości Filmowe” 1935, nr 12, s. 13. 
Projekcje w Famie trwały do 23 października 1933 roku. Następnie „film-kasa”, jak mówiono, był wyświetlany, za każdym razem z ogromnym powodzeniem, w największych skupiskach Żydów w Polsce. Od 21 listopada do 5 grudnia można go było zobaczyć w warszawskiej Lunie, a później między innymi w kinie Henryka w Rzeszowie, Czary w Łodzi, Cassino (czyli Grand Kino) w Piotrkowie[25] i Luna w Częstochowie. Na początku 1934 roku Józefa w Egipcie pokazywano w Zachęcie w Łodzi, Nowościach w Pabianicach, Corso w Lublinie i Marysieńce we Lwowie.

Gazety narodowe, jak na przykład wydawana w Kościanie „Gazeta Polska”, ostrzegały przed Józefem w Egipcie:

Film ten, produkcji żydowskiej, reklamowany szumnie jako „monumentalny”, największy po filmie pt. Ben Hur itp., jest po prostu kiczem. Tendencyjne przedstawienie proroctwa Jakóbowego jest więcej niż niewłaściwym; Jakób prorokuje o Mojżeszu, jako przyszłym Mesjaszu. Fatalnym i śmiesznym anachronizmem jest... mahometanin na dywaniku ze swym „Allah akbar” - za czasów Patriarchów. Film cały jest mówiony: w żargonie. Przekład polski bardzo niestaranny[26].

Nie opory natury estetycznej były jednak główną przyczyną ostrzeżenia, tylko nieskrywany antysemityzm redakcji „Gazety Polskiej”. Film jednak cieszył się ogromnym powodzeniem, przynosząc Greenowi jeszcze większe niż w Kanadzie dochody.

We Lwowie i w Częstochowie, a zapewne i w innych miastach, seanse uzupełniał jedenastominutowy dodatek Kol nidre, w którym tytułową pieśń wykonał kantor Leibele Waldman. Film ten zrealizował Sidney M. Goldin (jeden z najważniejszych twórców kina żydowskiego) dla wytwórni Judea Films, której właściciel, Joseph Seiden, na przełomie lat dwudziestych i trzydziestych wyprodukował dwie średniometrażowe fabuły oraz kilka krótkometrażówek dokumentujących występy wokalne sław estrady żydowskiej, między innymi Miriam Kressyn i Hymiego Jacobsona, a także pieśni religijne w wykonaniu znanych kantorów.

Zachęcony powodzeniem Green przystąpił do eksploatowania najnowszej produkcji jidyszowej w Stanach Zjednoczonych, filmu Bar micwa (Bar-mitzwah), którego premiera odbyła się 15 marca 1935 roku w Clinton Theater, w zamieszkanej głównie przez Żydów dzielnicy Lower East Side w Nowym Jorku. O ile Józef $w$ Egipcie był filmem zjidyszyzowanym, o tyle Bar micwa reprezentował już prawdziwe kino jidyszowe. Na podstawie sztuki, którą dekadę wcześniej napisał dla

[25] W kinie, znajdującym się przy placu Niepodległości 2, 14 grudnia 1933 roku „pożar wybuchł podczas wyświetlania filmu Józef $w$ Egipcie i błyskawicznie się rozprzestrzenił na cały budynek. Mechanik oraz dwóch strażaków odniosło dotkliwe poparzenia. Z publiczności nikt szwanku nie doznał. Budynek spłonął doszczętnie”. Zdarzenia $i$ wypadki ubiegłej doby, „Echo” 1933, nr 346, s. 2 (piątek, 15 grudnia 1933).
[26] Ostrzeżenie przed kiczem filmowym, „Gazeta Polska" 1934, nr 88, s. 1 (wtorek, 17 kwietnia 1934); zachowałem oryginalną ortografię. Wspomniany w artykule Ben Hur (Ben-Hur. A Tale of the Christ, 1925) w reżyserii Freda Niblo był wyświetlany w Polsce od stycznia 1927 roku. 
siebie Boris Thomashefsky, scenariusz opracował i film wyreżyserował pochodzący z Białegostoku Henry Lynn. Była to typowa produkcja szundowa. Jej bohaterka, Lea, żona Israela, pozostawia dwoje dzieci pod opieką męża i udaje się do Ameryki, aby odwiedzić matkę. Statek, którym podróżuje, tonie. Najbliżsi uważają, że kobieta nie żyje, ona jednak ocalała, lecz doznała amnezji. Po dziesięciu latach Lea odzyskuje pamięć i wraca do podwarszawskiej miejscowości, z której wyruszyła za ocean. Pozostaje incognito, bowiem wszystko komplikuje fakt, że Israel po latach samotności właśnie powtórnie się ożenił, a na następny dzień wyznaczona jest uroczystość bar micwy syna Lei i Israela... Łzawą, melodramatyczną fabułę dopełniono ośmioma piosenkami i jednym pokazem stepowania. Nie zabrakło tak wymyślnych scen, jak duet "dusz” chłopca i jego matki. Aktorzy grali z teatralnym rozmachem, sztucznym, patetycznym gestem, często wprost do kamery. Narracja, pełna niespodziewanych zdarzeń, rwała się raz po raz i nie motywowała precyzyjnie przebiegu akcji ani relacji między bohaterami. Proweniencja teatralna ciążyła, zdjęcia były prymitywne i wyglądały tak, jakby je zrealizowano nie w studiu, a w jakimś mieszkaniu (i chyba tak było).

Film Bar micwa od premiery 11 października 1935 aż do końca roku był grany w kinie Metro przy ulicy Smoczej $30 \mathrm{w}$ warszawskiej dzielnicy zamieszkanej głównie przez Żydów. Reklamowano go jako pierwszy „całkowicie mówiony po żydowsku”: „humor - pieśń - muzyka - sentyment”[27]. Program uzupełniono rewią Żyj i śmiej się! (Gelebt un gelacht) zrealizowaną w 1933 roku dla wytwórni wspomnianego już Josepha Seidena przez Maxa Wilnera i Sidneya M. Goldina. Wystąpił w niej Jossele Rosenblatt, sławny kantor palestyńsko-amerykański, wykonawca kadisz w Śpiewaku jazzbandu, a obok niego między innymi: Miriam Kressyn, Joseph Buloff, Hymie Jacobson oraz dwadzieścia girls; konferansjerkę prowadził Wilner. Mimo infantylizmu melodramat Bar micwa cieszył się w Polsce bardzo dużym zainteresowaniem, z powodzeniem był grany między innymi w Łodzi (kino Czary), Lwowie (Marysieńka), Lublinie (Corso) i Białej Podlaskiej (Alba)[28].

W następnych latach biuro Greena oferowało filmy z całego świata: amerykańskie, włoskie, angielskie, francuskie, często o tematyce żydowskiej, jak: Żyd Süss (Jew Süss, reż. Lothar Mendes, 1934) i Szir haszirim (Pieśń nad pieśniami, reż. Henry Lynn, 1935). Do dystrybucji Greena trafily także filmy na temat religii rzymskokatolickiej: Noc cudów (La Vierge du rocher, reż. Georges Pallu, 1933) - o cudach w Lourdes - i Don Bosco (reż. Goffredo Alessandrini, 1935) - o kanonizowanym w 1934 roku Janie Bosko[29]. Proponował ponadto między innymi:

[27] „Nasz Przegląd” 1935, nr 285, s. 1 (czwartek, 10 października 1935).

[28] Teatry żydowskie w Polsce wystawiały też sztukę Bar micwa. Ostatnia premiera odbyła się w getcie warszawskim w marcu 1942 roku w Teatrze Nowy Azazel przy ul. Nowolipie 72. Wystąpili w niej między innymi: Chana Lewin, Rita Gazel, Symche Fostel,
Chaim Sandler oraz Ajzyk Samberg, zarazem reżyser przedstawienia.

[29] Premiera, pod protektoratem Akcji Katolickiej i kardynała Augusta Hlonda, odbyła się 19 lutego 1937 roku w kinie Roma. „Film” 1936, nr 17, s. 17. Zob. także: „Film” 1936, nr 1, s. 8; Don Bosco, „Kino” 1937, nr 10, s. 2. 
Czu Czin Czou (Chu Chin Chow, reż. Walter Forde, 1934), Jasnowidza (The Clairvoyant, reż. Maurice Elvey, 1935), Droge do Rio (Cargaison blanche, reż. Robert Siodmak, 1937) oraz Jej pierwszy bal (Un Carnet du bal, reż. Julien Duvivier, 1937). Warszawskim biurem, które systematycznie poszerzało działalność, kierował M.E. Wekwajzer (Wekweiser), bowiem Green skupił się na działalności producenckiej. W tym celu w Nowym Jorku, w budynku Paramountu przy 1501 Broadway Street, założył Sphinx Films Corp. - ekspozyturę swojej warszawskiej firmy.

Wspomnienia z planu Śpiewaka jazzbandu w połączeniu $\mathrm{z}$ ogromnym zainteresowaniem nawet tak słabymi produkcjami, jak Józef w Egipcie i Bar micwa, zainspirowały Greena do realizacji filmów $\mathrm{w}$ Polsce. W połowie lat trzydziestych minęły już pierwsze zachwyty samym faktem, że z ekranu można było słyszeć język jidysz. Krótkometrażówki oraz produkcje szundowe przestały wystarczać publiczności żydowskiej. Green był świadom tego. Rozrzuconym po całym świecie Żydom chciał przypominać ziemie, które opuścili, a które $z$ oddalenia przestrzennego i czasowego wywoływały nostalgię. Miał zamiar przywoływać świat żydowski nie tylko z powodów sentymentalnych, ale by włączyć się do budowania i umacniania tożsamości żydowskiej, które to zadanie należało wcześniej do religii, literatury i teatru. Myśląc o przyszłej szerokiej dystrybucji, za wzór stawiał sobie Hollywood, w którym powstawały wysokobudżetowe, dopracowane technicznie produkcje, a nie Nowy Jork, stolicę szundu. Realizacja filmu w Polsce kosztowała od 80 do 140 tysięcy złotych i to zdobytych z największym trudem od licznych inwestorów[30]. Green dysponował wielokrotnie wyższym i to własnym kapitałem, dzięki któremu miał najlepszą z możliwych ekipę techniczną, studio, nowy sprzęt, a przede wszystkim pełną niezależność.

Judel gra na skrzypcach
Green chciał stworzyć film rozrywkowy, zakorzeniony w folklorze. Przebywając w Warszawie w środowisku żydowskich dziennikarzy, pisarzy i muzyków, zetknął się z cenionym poetą Icykiem Mangerem. W połowie lat trzydziestych Manger pracował nad przeróbką klasycznej operetty Czarownica (Di kiszefmacherin) Abrahama Goldfadena - ojca teatru żydowskiego. Głównym bohaterem uczynił Hocmacha, który sierotkę Mirele chroni przed złowrogą czarownicą. Green zainteresował się przeróbką Mangera i do współpracy, jako aktora i współreżysera, pozyskał goszczącego wtedy w Warszawie Maurice’a Schwartza, który dziesięć lat wcześniej (1924) wystawił Czarownicę w nowojorskim Jidiszer Kunst-Teater. Jednak wkrótce ich drogi się rozeszły[31], bowiem Schwartz zaproponował sfilmowanie - w miejsce Czarownicy - Tewjego
[30] Zob. E. Zajiček, Poza ekranem. Kinematografia polska 1918-1991, Warszawa 1992, s. 20-21.

[31] Wersja Czarodziejki (Babe Jachne) w przeróbce Mangera (z trzema Hocmachami zamiast jednym) należała do najważniejszych premier Teater far Jugnt (Teatru dla Młodzieży) Klary Segałowicz. Premiera odbyła się 5 marca 1937 roku w Warszawie w reżyserii Jakuba Rotbauma, w dekoracjach Jana Kosińskiego i z muzyką Henocha Kona. Babe Jachne zagrała Dina Halpern, Mirele - Klara Segałowicz, a Pierwszego Hocmacha - Maks Bożyk. 
mleczarza (Tewje der milchiker). Sztuką, napisaną według prozy Szolema Alejchema, Schwartz otworzył w swoim teatrze sezon 1919/1920 i grał w niej wielokrotnie rolę tytułową. Green odrzucił propozycję Schwartza. Chciał filmu lekkiego, rozrywkowego, a nie dramatu ojca, Żyda, wygnańca. Uznał też, że główny konflikt - żydówki, która się ochrzciła, aby zostać żoną Ukraińca, i walka ojca o jej duszę z popem[32] - byłby zbyt drażliwy w ówczesnej, coraz bardziej antysemickiej Polsce.

W Paryżu występowała wówczas Malka (Molly) Picon, „królowa” (to właśnie znaczy hebrajskie imię Malka) teatru i kabaretu jidyszowego w Stanach Zjednoczonych, mająca też za sobą doświadczenia filmowe[33]. Jej klasę aktorską i popularność Green znał doskonale z Nowego Jorku. Także publiczność kilku miast polskich mogła ją dobrze pamiętać Z występów (1920, 1922, 1933), między innymi w nowej wersji sztuki Izydora Zołotarewskiego Jankiel, chłopiec z jesziwy (Jankele gejt in szul arajn / Jankele, jesziwe bocher), przygotowanej przez Jakoba Kalicha (męża Picon) i Borisa Rosenthala. Picon zagrała tam tytułową rolę, trzynastoletniego chłopca, który nie chce uczyć się w jesziwie.

Właśnie z myślą o Picon zamówił Green scenariusz u Konrada Toma. Tom był jedną z ważniejszych postaci branży filmowej w Polsce: aktorem, scenarzystą, dialogistą, autorem piosenek i reżyserem, znakomicie czującym kino rozrywkowe. Miał też duże doświadczenie kabaretowe. Być może Green pamiętał Toma jeszcze z czasów łódzkich, gdy ten w latach 1912-1914 pracował w miejscowej prasie, a na początku 1914 roku w hotelu Savoy przy ulicy Krótkiej 6 (obecnie Traugutta) współtworzył kabaret Bi-Ba-Bo. Tom naszkicował scenariusz o narzeczonej przeznaczonej staremu mężowi, której w ucieczce spod chupy pomagają wędrowni muzykanci. Nie była to jednak rola, którą Green mógłby zaproponować Picon, toteż po kilku miesiącach wspólnej pracy z Tomem [34] stworzył scenariusz o młodym klezmerze, którym w rzeczywistości jest dziewczyna przebrana za chłopaka. Pamiętał zapewne, że aktorka miała spore doświadczenie w odtwarzaniu ról „spodenkowych” - tytułowego „chłopca z jesziwy” grała około trzech tysięcy razy. Wątkiem dopełniającym uczynił konflikt dwóch duetów klezmerskich, który z czasem przeradza się we wspólne muzykowanie; motyw uciekającej narzeczonej został zepchnięty na drugi plan. Z tym scenariuszem na początku maja 1936 roku Green pojechał do Paryża, gdzie w teatrze Alhambra - obok innych wykonawców - występowała Picon, wykonując z powodzeniem piosenki aktorskie, zarówno jidyszowe, jak i francuskie, między innymi Yiddisch, Notre langue, Le petit bonhomme, Le monde est un théâtre, Mes millions, Ma famille[35].

[32] Taki był centralny motyw inscenizacji teatralnej Schwartza. Zob. M.K. [M. Kanfer], Morris Schwarz jako Towje Mleczarz, „Nowy Dziennik” 1935, nr 356, s. 7 (poniedziałek, 30 grudnia 1935).
[33] aw., Kim jest Molly Picon?, „Film” 1936, nr 9, s. 14. [34] Der najer jidiszer film "Jidl mitn fidl” [Nowy film jidyszowy „Judel gra na skrzypcach”], „Literarisze Bleter" 1936, nr 39, s. 625.

[35] J.B., La Colonie scolaire, „L'Univers Israélite” 1936, nr 33, s. 523. 
Picon zaakceptowała scenariusz, tym bardziej, że od dawna sama myślała o realizacji filmu jidyszowego[36]. Istotnym argumentem musiało być także honorarium $\mathrm{w}$ wysokości dziesięciu tysięcy dolarów - najwyższe jakie wówczas zapłacono w kinie żydowskim, a dodatkowo udział we wpływach z eksploatacji. Kalich objął kierownictwo artystyczne przygotowywanej produkcji, a pianista Abraham Ellstein, towarzyszący Picon w występach, został zaangażowany do skomponowania muzyki do wierszy Icyka Mangera. Tytuł filmu - Judel gra na skrzypcach (Jidl mitn fidl) - wymyślono dopiero tuż przed rozpoczęciem zdjęć. Green chciał nawiązać współpracę reżyserską z Michałem Waszyńskim, ten jednak nie był nią zainteresowany[37]. Ostatecznie zaangażował polskiego reżysera Jana Nowinę-Przybylskiego. Green odpowiadał za pracę z głównymi aktorami, panowanie nad resztą realizacji pozostawiając bardziej doświadczonemu Nowinie-Przybylskiemu, który miał już na koncie pięć samodzielnie wyreżyserowanych filmów. Gdy 10 lipca 1936 roku Picon i Kalich dotarli do Warszawy, sześćdziesięcioczteroosobowa ekipa mogła wkroczyć do nowo zbudowanego przy ulicy Chopina, w tak zwanej Dolinie Szwajcarskiej, atelier Falangi. W obsadzie, oprócz Molly Picon w roli Itke/Judela, znaleźli się, między innymi: Chana Lewin, Dora Fakiel, Basia Liebgold, Maks Bożyk, Maks Bryn, Symche Fostel, Abraham Kurc, Samuel Landau i Leon Liebgold. Ekipę techniczno-organizacyjną tworzyli: operator Jakub Joniłowicz, dekorator Jacek Weinreich, kierownicy produkcji Edward Hantower i Józef Frankfurt oraz Czesław Piaskowski, który wraz z Kalichem sprawował kierownictwo artystyczne. Nieformalnym współpracownikiem była żona Greena[38]. Urodzona 15 marca 1908 roku w Warszawie jako Chana Rynd, córka Lejzora, technika drukarskiego mieszkającego przy ulicy Leszno 6/30, została żoną Greena zapewne około 1935 roku; z czasem zmieniła imię na Anette.

Producenci filmowi udają się w dzikie ostępy Afryki, aby uzyskać prawdziwy obraz życia nad rzeką Ubangi, jeżdżą do serca Meksyku, by zdobyć autentyczne sombrero, ale żeby zobaczyć ortodoksów w jarmułkach, z rozwianymi brodami i pejsami, musimy jechać do Kazimierza, małej wioski, w której urodziła się jedyna, dotychczas, żydowska królowa Polski[39]

- pisała Molly Picon. W Kazimierzu nad Wisłą w 1925 roku nakręcono film Jeden z 36 (Lamedwownik, reż. Henryk Szaro), tu też w 1937 roku powstanie Dybuk (reż. Michał Waszyński). Miasteczko wspominane jest również w Wuju Mosesie. Tam też, w archetypicznym sztetlu, nakrę-

[36] Zob. J. Finkelstein, W towarzystwie Eliszewy i Mali Picon (Korespondencja własna „Chwili”), „Chwila” 1931, nr 4544, s. 11 (środa, 10 listopada 1931); (r-s.), W drodze z Palestyny do Moskwy. Przy czarnej kawie z Mali Pikon i J. Kalichem, „Nasz Przegląd” 1933, nr 147, s. 7 (sobota, 27 maja 1933).

[37] Recenzując filmowego Dybuka, Mojżesz Kanfer napisał przy okazji: „Przed rokiem zaproponowano mu [Waszyńskiemu] reżyserię żydowskiej komedii muzycznej z wybitną aktorką żydowsko-amerykańską w roli głównej. Ale wtenczas p. Waszyński propozycję tę odrzucił, bo to go specjalnie nie pociągało”. Moasi [M. Kanfer], Z ekranu: „Dybuk”, „Nowy Dziennik” 1937, nr 259, s. 15 (wtorek, 21 września 1937). [38] M. Picon (i J.B. Grillo), Molly!, New York 1980, s. 67 .

[39] M. Picon, Fiddling in Old Kazmierz, „The New York Times” 1937, nr 10, s. 5. 
cono znaczną część zdjęć do Judela... Do zrealizowania sceny weselnej wszystko przygotowano jak do prawdziwego wesela, z dużą ilością koszernego jadła i biedotą sproszoną na ucztę, przy czym statyści nie mieli świadomości, że znajdują się na planie filmowym. Zdjęcia do tej sceny, rozpoczęte o 11.00, zakończyły się następnego dnia nad ranem, a przyśpiewki na temat państwa młodych nakręcono jeszcze później. W sumie wszystkie kazimierskie zdjęcia Judela... powstały w ciągu dwóch tygodni. Trwały tak długo, ponieważ do jednej ze scen, do której potrzebnych było sześćdziesięciu statystów z powodu nieporozumień językowych, z bliższych i dalszych okolic ściągnęły do miasteczka setki chłopów z końmi, kozami i krowami, zachęconych możliwością zarobienia pięciu złotych[40]. Mimo tych drobnych trudności realizacja zdjęć przebiegła w sumie sprawnie.

Następnie kręcono w atelier przy ulicy Chopina w Warszawie, które według Molly Picon było

w pełni wyposażone, $\mathrm{z}$ równo rozłożonymi kablami, tak jak w dużych amerykańskich studiach; precyzyjna organizacja czasu pracy, dobra informacja, sygnalizacja świetlna, reżyserzy w pumpach, megafony, żółwie tempo pracy maszynistów i ciągle słyszane „pshakrev”[41].

Koszt filmu Judel gra na skrzypcach wyniósł dwieście tysięcy złotych[42]. Zrealizowana z równym rozmachem produkcja w Stanach Zjednoczonych kosztowałaby cztery-pięć razy więcej.

Reklamowany niekiedy jako „największy polski film w jęz. żyd. produkcji polskiej"[43], Judel gra na skrzypcach miał premierę 30 września 1936 roku, w przeddzień święta Sukkot, w reprezentacyjnym warszawskim kinie Sfinks przy ulicy Senatorskiej 29. W październiku był wyświetlany w Apollu w Grodnie, Oazie w Kaliszu, Adrii w Krakowie, Marysieńce we Lwowie, Olimpii w Przemyślu, Apollu w Rzeszowie, Palace w Sosnowcu, Panie w Wilnie i Warszawie w Stanisławowie. Wszędzie odniósł ogromny sukces. Należał do najbardziej kasowych produkcji polskich 1936 roku.

Judel gra na skrzypcach trafil także za granicę, przede wszystkim do Stanów Zjednoczonych. Premiera z angielskimi napisami odbyła się w wieczór sylwestrowy 1936 roku w reprezentacyjnym Ambassador Theater na Broadwayu. Film został znakomicie przyjęty przez prasę. W opiniotwórczym „Variety” napisano, że „mimo pewnych zastrzeżeń jest to wartościowy film żydowski”[44]. W Ambassadorze Judel... był grany przez sześć tygodni, a następnie trafił do kilku innych kin należących do liczącej się sieci dystrybucyjnej Loew's (Loew's Theatres). W sumie w Nowym Jorku wyświetlano go do wiosny 1937 roku. Pokazywany był też między innymi w Austrii, Belgii, Francji, Holandii, Jugosławii, Wielkiej Brytanii, Argentynie, Afryce Południowej i Australii, a także,

[40] J.N. Goldberg, op.cit., s. 106. Według Molly Picon (Fiddling in...) zdjęcia trwały dziesięć dni, a dniówka dla statysty wynosiła dwa złote.

[41] M. Picon, Fiddling in...
[42] Der najer jidiszer film...

[43] „Film” 1936, nr 13, s. 22.

[44] Edga., „Yiddle With His Fiddle” (Polish Made), „Variety” 1937, nr 4, s. 41. 
z dubbingiem w języku hebrajskim, w Palestynie. W kwietniu 1938 roku wyświetlano go w skupiskach żydowskich na terenie Trzeciej Rzeszy[45].

Na tle wcześniejszych produkcji polskich, nie tylko jidyszowych, komedię Greena wyróżniał staranny dobór tematu, dopracowany scenariusz, dobrzy aktorzy, kultura realizacji i wysoka jakość techniczna. O swoim programie artystyczno-produkcyjnym opowiedział Green przedstawicielowi tygodnika literackiego „Literarisze Bleter”, w rozmowie opublikowanej w numerze z 25 września 1936 roku, czyli pięć dni przed warszawską premierą Judela:

Zainwestowaliśmy bardzo dużo pieniędzy, ponieważ postawiliśmy sobie zadanie zrobienia dobrego filmu. Musieliśmy jednak liczyć się ze stroną komercjalną i dlatego byliśmy zmuszeni wyprodukować film przystępny dla jak najszerszych warstw. Przy filmie żydowskim trzeba wziąć pod uwagę to, że liczba widzów jest raczej ograniczona, dlatego musiałem uwzględnić także publiczność nieżydowską.

Wytyczyłem sobie następujące cele:

1) Stworzyć wszelkie możliwości techniczne mogące postawić film na właściwym poziomie realizacyjnym;

2) Temat filmu powinien być żydowski, ale ogólnoludzki i europejski zarazem. Na ile to możliwe unikać Żyda galutowego i chałatu, pozostawiając tradycję o tyle, o ile przydaje ona filmowi kolorytu. Zachować pewien umiar w kwestii żydowskiego folkloru i etnografii. Chciałbym również, by niesprawiedliwości społecznej nie ukazywać poprzez krzykliwą propagandę, lecz poprzez czysto artystyczne momenty. Takie emocje, jak radość, cierpienie, przeżywanie, są przecież ogólnoludzkie;

3) Film powinien nieść wartości kulturalne, odznaczać się czystością żydowskiego języka, folkloru i etnografii, a zarazem zapewniać rozrywkę. Dużą wagę przyłożyłem także do strony muzycznej filmu. Jest w nim dużo muzyki. Występują obok siebie motywy ludowe i nowoczesne.

4) Gra aktorów powinna nadać filmowi wysoką jakość artystyczną[46].

Program ten Green z powodzeniem będzie realizował także $\mathrm{w}$ następnych swoich produkcjach.

\section{Błazen purymowy}

W marcu 1937 roku Anette Green, na prośbę męża, udała się z krótką wizytą do Stanów Zjednoczonych, gdzie skontaktowała się z kilkoma scenarzystami. A już w maju małżonkowie popłynęli razem do Nowego Jorku, gdzie Green spotkał się z Gershonem Einbinderem, urodzonym w miasteczku Berszad na Ukrainie, lewicowym dziennikarzem, nauczycielem i autorem książek dla dzieci, między innymi purymowej sztuki Haman chce ukraść kołatki (Homen wil cuganwenen dem grager). Główne dziedziny aktywności Einbindera znalazły odbicie w pseudonimie, którym się podpisywał: Chaver-Pahver. „Chawer” to po żydowsku „towarzysz”, a „pahver” to dziecięcy, nic nieznaczący rym do pierwszego wyrazu. Green zakupił u niego pomysł na film Błazen purymowy (Der purymszpiler), po czym samodzielnie opracował

[45] J. Hoberman, op.cit., s. 242, 254-255.

[46] Der najer jidiszer film... Tłumaczenie tego tekstu z: N. Gross, Film żydowski w Polsce, przeł. A. Ćwia- kowska, Kraków 2002, s. 75 na użytek niniejszego artykułu skorygował Krzysztof Niweliński. 
scenariusz. O ile w Judelu... ważną rolę odgrywały folklor i piosenka żydowska, o tyle Błazen... nawiązywał do teatru żydowskiego, który wyrósł z przedstawień purymowych. Dlatego też do napisania dialogów i piosenek zatrudnił Icyka Mangera. Pamiętał dobrą z nim współpracę przy Judelu..., ale ważniejsze było chyba to, że w 1936 roku Manger wydał Wiersze ze zwoju Estery (Megile lider), zbiór lirycznych dramatów utrwalających tradycję przedstawień purymowych.

Rolę tytułową Einbinder przewidział dla Josepha Buloffa, kolegi Greena z Trupy Wileńskiej, a później gwiazdora scen żydowskich w Nowym Jorku. Buloff jednak został zatrudniony w Theatre Guild na Broadwayu i zrezygnował z przyjazdu do Polski. W tej sytuacji Green, aby nie opóźniać realizacji, zaangażował, choć bez szczególnego przekonania, Zygmunta Turkowa, aktora warszawskich teatrów żydowskich. Turkow właśnie ukończył pracę na planie Ślubowania (Tkijes chaf, 1937), gdzie zagrał proroka Eliasza (jak w wersji z 1924 roku, którą też sam wyreżyserował) i wspomagał reżysersko Henryka Szaro[47].

Gwiazdami Błazna purymowego była para aktorów z Jidiszer Kunst-Teater, a prywatnie małżeństwo: urodzona w Białymstoku Miriam Kressyn w roli Estery i Hymie Jacobson grający cyrkowca Dicka. Miłość granych przez nich bohaterów - córki szewca i wędrownego artysty - obserwuje i wspomaga zakochany w dziewczynie tytułowy bohater. Na marginesie trudno nie zauważyć, że był to już drugi (i nie ostatni) film, w którym Green opowiadał się przeciw zwyczajowi aranżowania małżeństw. W Błaźnie purymowym zagrali również między innymi: Ajzyk Samberg - niegdyś aktor z Wilner Trupe, Maks Bożyk, Maks Bryn oraz Samuel Landau. Z ekipy Judela... na plan Błazna trafili: dekorator Jacek Weinreich i kierownik produkcji Edward Hantower. Nowy natomiast był operator - Seweryn Steinwurzel. Nieporozumieniem okazało się zaangażowanie Nicholasa Brodszky’ego, doświadczonego rosyjsko-węgierskiego kompozytora, pracującego w różnych krajach, który jednak nie czuł muzyki żydowskiej. Aktorów prowadził Green, inscenizacja planu należała ponownie do Nowiny-Przybylskiego.

Zdjęcia przedstawiające rynek Kazimierza nad Wisłą nakręcono w dekoracjach zbudowanych na terenie Fermy Rolniczej Hechaluc-Pionier - gospodarstwa, w którym chalucowie, czyli pionierzy wybierający się do Palestyny, uczyli się pracy na roli; znajdowała się ona na warszawskim Grochowie przy ulicy Witolińskiej 43. Sceny z udziałem prawdziwego cyrku powstały $\mathrm{w}$ atelier[48]. Zdjęcia na krakowskim Kazimierzu Green zamierzał zrealizować z udziałem żydów ortodoksyjnych, jednak ich religijnie motywowany opór sprawił, że ostatecznie zaangażował aktorów. Realizacja zdjęć przy udziale osiemdziesięcioosobowej ekipy zajęła siedem tygodni.

Rola tytułowa została pomyślana zbyt poważnie jak na pozycję rozrywkową. Zagranie postaci, w której zostały połączone cechy Żyda

[47] Zob. R. Włodek, Wileńska opowieść, „Midrasz” 2011, nr 4, s. 41.
[48] J. St., Śmiej się pajacu... Reportaż z atelier, „Kino” 1937, nr 33, s. 11. 
Wiecznego Tułacza i Chaplinowskiego włóczęgi, przekroczyło możliwości Turkowa.

Jest po trosze patetyczny (ale patos fałszywy), niedociągnięty, odrobinę śmieszny, a najmniej tragiczny. Słowem nijaki. Jacobson natomiast nie grzeszy urodą (co jest nieodzownym warunkiem, i żeby go dziewczyna pokochała, i aby zaskarbił sobie sympatię publiczności) ani też talentem, czy kunsztem tanecznym. Sprowadzenie tego artysty z Ameryki było - jak sądzić można - złem koniecznym albo, jeśli kto chce inaczej, koniecznym dodatkiem do Miriam Kressin[49].

Premiera Błazna purymowego w znanej już Greenowi warszawskiej Famie odbyła się 18 września 1937 roku, dwa dni przed Sukkot. Miesiąc później, w połowie października, Green udał się z żoną do Stanów Zjednoczonych. Amerykańska premiera odbyła się 5 grudnia 1937 roku w Cameo Theater (należącym do sieci Loew's) przy 42 Ulicy Wschodniej na Broadwayu. Trzy dni później w „Variety” napisano, że The Jester (angielski tytuł filmu) „będzie się podobał określonym grupom, którym można go pokazać w Stanach Zjednoczonych"[50]. Trafił także do kilku innych krajów, między innymi Francji, oraz do ośrodków diaspory żydowskiej, jednak nigdzie nie zyskał popularności porównywalnej z tą, jaką osiągnął Judel gra na skrzypcach. W 1940 roku sceny przedstawienia purymowego z Błazna purymowego niemiecki propagandzista Fritz Hippler włączył do zrealizowanego przez siebie antysemickiego filmu dokumentalnego Wieczny Żyd / Żyd wieczny tułacz (Der ewige Jude).

Mateczka i List do matki
Po Błaźnie purymowym Green postanowił zrealizować melodramat na temat głęboko zakorzeniony w obyczaju i kulturze żydowskiej: emigracji, rozpadu rodziny, tęsknoty, odnalezienia po latach zagubionego dziecka[51]. Pomysł scenariuszowy nie był oryginalny. W 1911 roku w Rosji powstał film oparty na słowach popularnej kołysanki pod niemiecko-jidyszowym tytułem Ein briffur di mutter (List do matki). Jej autorem był urodzony w Pińsku Solomon Szmulewicz, twórca ponad pięciuset pieśni, które napisał po wyemigrowaniu do Stanów Zjednoczonych. Jedna z nich, List do matki (A briwele der mamen), Z 1907 roku (wkrótce nagrana na płytę w wytwórni Victor), bardzo szybko zyskała dużą i trwałą popularność we wszystkich skupiskach żydowskich. Zainspirowany nią tragikomiczny, dziewięciominutowy film pod tym samym tytułem od września 1911 roku prezentował bliżej nieznany Abram M. Smoleński - „aktor z Warszawy”[52], podczas projekcji osobiście objaśniając przebieg akcji. Sukces, przez co należy rozumieć wyeksploatowanie kopii aż do jej fizycznego zniszczenia,
[49] Błazen, „Prawda o Filmie” 1937, nr 7, s. 10. [50] Cyt. za: Halo! Tu Ameryka. Ameryka o Polsce: „Love of A Kingdom” („Miłość lub Królestwo”); „Der Purymspieler”, „Prawda o Filmie” 1938, nr 1, s. 4. [51] Zob. R. Włodek, Bezdomni. Motyw emigracji w filmach jidyszowych, [w:] Przestrzeń w kulturze współczesnej: literatura, teatr, film, red. D. Mazur i B. Morzyńska-Wrzosek, Bydgoszcz 2016, s. 428-440. [52] W.M. Korotkij, Opieratory i reżissiery russkogo igrowogo kino 1897-1921. Biofilmograficzeskij sprawocznik, Moskva 2009, s. 343. 
spowodował, że już po roku Smoleński nakręcił w Jekaterynosławiu (obecnie Dniepr na Ukrainie) nową wersję. Jej premiera odbyła się w listopadzie 1912 roku.

Green samodzielnie naszkicował pomysł filmu List do matki. Na jego podstawie Mosze Oszerowicz, emigrant z Wołynia, dziennikarz nowojorskiego „Jewish Daily Forward”, w ciągu dwóch miesięcy napisał scenariusz. Oszerowicz rozbudował znacznie problematykę rodzinną. Tęsknota matki za synem stanowi główny, ale nie jedyny wątek filmu. Wiodące role zagrało małżeństwo aktorów teatralnych Lucy i Misza Germanowie, które też miało za sobą doświadczenie emigracji do Ameryki. Po niepowodzeniach z Brodszkym do skomponowania muzyki i piosenek Green zaangażował ponownie Ellsteina.

Pojawiły się jednak komplikacje, bowiem Jakob Kalich zaproponował Greenowi nakręcenie kolejnego filmu z nadal niezwykle popularną Molly Picon. Green nie miał pomysłu na scenariusz oryginalny, toteż zaakceptował propozycję Kalicha, by sfilmować komedię Mateczka (Mamele) Meyera Schwartza, w której od 1926 roku, z sukcesem, występowała Picon (w reżyserii Kalicha). Green zabrał scenariusz do Polski i ponownie powierzył go do opracowania Konradowi Tomowi, który dokonał zamiany realiów Lower East Side, gdzie pierwotnie toczyła się akcja sztuki, na łódzkie. Zastąpił też zmarłego 23 maja 1936 roku Nowinę-Przybylskiego na stanowisku współreżysera. Kilku współpracowników pozyskał Green z kręgu artystów skupionych wokół Mojżesza Brodersona (teatrzyk marionetek Chad Gadje, teatrzyk rewiowy Ararat): dialogi napisali Mojżesz Nudelman, satyryk, i Szmulik Goldsztejn, zarazem komik, znany z groteski filmowej Weseli biedacy (Frejleche kabconim, reż. Leon Jeannot i Zygmunt Turkow, 1937). Kierownictwo literackie sprawował Jecheskiel Mosze Neumann, dziennikarz, krytyk, także autor monologów i skeczów teatralnych oraz scenarzysta filmowy (Za grzechy [Al chet], reż. Aleksander Marten, 1936; Ślubowanie). Kierownikiem artystycznym został Kalich, który przybył do Polski przed Picon, aby wszystko przygotować. Gwiazda filmu przypłynęła z Hoboken na statku „Piłsudski” w czerwcu 1938 roku, czyli tuż przed rozpoczęciem zdjęć.

Akcja została umiejscowiona w Łodzi - rodzinnym mieście Greena. Kilka scen nakręcono na ulicach Bałut oraz przy Ogrodowej 3, obok budynku fabrycznego Poznańskich[53]. Zdjęcia plenerowe zrealizowano także w Ciechocinku, między innymi przy basenie termalno-solankowym, stawie z łabędziami, muszli koncertowej oraz drewnianym dworku przy ulicy Zdrojowej. Na początku lipca ekipa przeniosła się do studia w Warszawie.

Molly Picon, wówczas czterdziestoletnia, wcieliła się w postaci czterech kobiet w różnym wieku, w tym w dwunastolatkę... Skoro podobnie ryzykowny zabieg spodobał się w Judelu, dlaczego nie miałby się

[53] H. Krajewska, Życie filmowe Łodzi w latach 1896-1939, Warszawa-Łódź 1992, s. 200. 
udać i tym razem? Jej bohaterka, tytułowa „mateczka”, stara się zastąpić rodzinie nieżyjącą matkę. Jest nadopiekuńcza w stosunku do wszystkich: ojca, siostry, braci, co powoduje, że jest przez nich nieustannie wykorzystywana. Wreszcie przystojny sąsiad wyrywa ją z tej toksycznej, choć komediowo ukazanej rodziny.

Według napisów czołowych asystentem reżysera był J. Grynberg - zapewne Ilia Grynberg, szwagier Josepha. Przy obu filmach pracowała w zasadzie ta ekipa, która częściowo ukształtowała się przy produkcji Błazna purymowego: Neuman, Frankfurt, Hantower i Steinwurzel. Muzykę i piosenki skomponował Abraham Ellstein, z którym Green współpracował przy Judelu..., a dekoracje przygotowali Jacek Rotmil i Stefan Norris. Także niektórzy aktorzy zagrali w obu filmach: Gertrude Bullman, Maks Bożyk, Adam Domb, Symcha Fostel, Leon Kaswiner, Edward Sternbach i Edmund Zayenda. Ponadto w Mateczce wystąpili między innymi: Maks Bryn i Menasze Oppenheim, a w Liście do matki: Chana Lewin i Samuel Landau.

Zdjęcia do Mateczki zajęły w sumie sześć tygodni i dopiero po ich zakończeniu rozpoczęto realizację Listu do matki. Na to przyśpieszenie wpływ miały zapewne nie tylko względy ekonomiczno-organizacyjne, ale i coraz bardziej pogarszająca się sytuacja Polski, tak wewnętrzna $\mathrm{z}$ narastającym antysemityzmem, jak i zewnętrzna - z zagrożeniem ze strony Trzeciej Rzeszy. Green chyba przeczuwał, że nie będzie miał dłużej możliwości realizowania filmów jidyszowych w Polsce. Premiera Mateczki odbyła się 24 września 1938 roku, dwa dni przed Rosz ha-szana. Film cieszył się sporym zainteresowaniem. W Nowym Jorku był pokazywany od 25 grudnia 1938 roku.

Do współreżyserowania Listu do matki Green zatrudnił Leona Trystana, twórcę komedii Piętro wyżej (1937). W styczniu 1938 roku Kinopol, zajmujący się dystrybucją filmów polskich w Stanach Zjednoczonych, wprowadził Piętro wyżej na ekrany kin nowojorskich; wprawdzie pod angielskim tytułem The Apartment Above (w późniejszej literaturze występuje też pod tytułem One Floor $U_{p}$ ), ale $\mathrm{w}$ oryginalnej wersji językowej $\mathrm{z}$ angielskimi napisami. Pokazy nie przyniosły twórcom oczekiwanych sukcesów[54]. Ogromna popularność fokstrota Sexappeal to nasza broń kobieca z Piętra wyżej w wersji jidyszowej (tłumaczenie Samuel Korntayer, wykonanie Menasze Oppenheim) podpowiedziała Jerzemu Szafirowi i Ludwigowi Prywesowi, krajowym posiadaczom praw do sprzedaży filmu za granicę, zmianę strategii. Na ich zlecenie w połowie 1938 roku Polska Spółka Synchronizacyjna, Sp. z o. o. w Warszawie, Jerozolimska 43[55], we współpracy z pisarzem i satyrykiem Józefem Tunkelem zdubbingowała Piętro wyżej w jidysz.

Green, doceniając sprawność reżyserską Trystana i zapewne przewidując sukces jego filmu w wersji jidyszowej u widzów żydow-

[54] Zob. J.N. Goldberg, Laughter through Tears..., op.cit., s. 114; E.A. Goldman, Visions, Images..., s. 107; J. Hoberman, Bridge of Light..., op.cit., s. 190-191.
[55] „Piętro wyżej” po żydowsku, „Film” 1938, nr 25, s. 4 . 
skich[56], zatrudnił go jako współpracownika przy Liście do matki. W nadaniu ostatecznego kształtu scenariuszowi Oszerowicza uczestniczyli wspomniany już Neumann oraz Anatol Stern, autor scenopisu.

Tragiczny los matki rodziny żydowskiej, matki, którą opuszcza mąż, a z kolei wszystkie jej dzieci, to treść filmu, to treść fabuły logicznie zestawionej w poszczególnych zdarzeniach. Wszystko jest tam na swoim miejscu, wszystko ze sobą się łączy, jedno z drugiego wypływa i ma równy bieg wydarzeń. I nawet ta emigracja do Ameryki, do tej Ameryki, która jest ziemią marzeń milionów ludzi, rozproszonych po całym świecie, a z której dochodzą listy dobre i złe, listy o życiu i śmierci, listy, których oczekują miliony matek żydowskich - ma swoją prawdziwą łączność z życiem i niedolą żydowskiego ludu[57].

Scenarzyści zaakcentowali konieczność pielęgnowania tradycji. Tytułowa kołysanka $A$ briwele der mamen, niegdyś śpiewana w rodzinnym Lubomlu, przekształcona we Wspomnienie o domu rodzinnym, po latach rozłąki pozwala matce odnaleźć syna i symbolicznie scalić rodzinę.

We wszystkich filmach Greena zostały utrwalone tradycyjne obrzędy żydowskie. W Judel gra na skrzypcach były to zaślubiny i wesele, w Błaźnie purymowym - przedstawienie purymowe, w Mateczce - Sukkot. W Liście do matki można zobaczyć wieczór sederowy, poprzedzający Pesach. W czasie tego święta, upamiętniającego wyjście Izraelitów z Egiptu, czytana jest Hagada podejmująca podstawowy dla Żydów problem asymilacji. Zgodnie ze zwyczajem w czasie kolacji sederowej najmłodszy syn zadaje ojcu cztery pytania. W Liście do matki chłopiec wygłasza wstępną formułę: „Czym różni się ta noc od wszystkich innych nocy?” i zadaje pierwsze: „We wszystkie inne noce w roku spożywamy chleb kiszony lub niekiszony, nocy tej jedynie niekiszony?". Drugiego pytania nie jest w stanie wypowiedzieć z powodu wybuchu szlochu z lęku o los ojca.

Lucy German w roli matki próbującej utrzymać więzi rodzinne zyskała olbrzymią popularność. Stworzyła „silną, niezatartą w wrażeniu postać bohaterskiej matrony żydowskiej” [58] - dramatyczną, poważną wersję komediowej „mateczki” granej przez Molly Picon.

W reklamach zamieszczonych w tygodniku „Film” można było przeczytać, że premiera Listu do matki odbędzie się równocześnie w kilku miastach[59], w których zamieszkuje najwięcej Żydów. Nie doszło do zapowiadanej na 3 marca 1939 roku warszawskiej premiery w kinie Sfinks. Natomiast tego dnia film zaczęto wyświetlać we Lwowie w Marysieńce. Od 13 marca ta „modlitwa poranna serc macierzyńskich,

[56] I nie pomylił się. Od grudniu 1938 roku Piętro wyżej, wprowadzone przez spółkę Best Films na ekrany kin amerykańskich jako Sąsiedzi (Szchejnim), cieszyło się dużą popularnością. Producenci w Stanach Zjednoczonych, głównie w początkach kina dźwiękowego, wielokrotnie dostosowywali filmy, w których występują wątki judaistyczne, do potrzeb widowni żydowskiej. Piętro wyżej natomiast to jeden z nielicznych przykładów zjidyszyzowania filmu nie- podejmującego tematyki żydowskiej. Zob. R. Włodek, Na początku było „Le'chajim”. Bardzo krótka historia kina żydowskiego, Szczecin 2013, s. 28. [57] E. Igel, Film żydowski. „List do matki” - Kino Marysieńka, „Chwila” 1939, nr 7170, s. 9 (czwartek, 9 marca 1939).

[58] Ibidem.

[59] „Film” 1939, nr 7, s. 15 oraz nr 9-10, s. 26. 
[...] dramat emigrantów żyd. i ich matek, [...] tragedia ludu żydowskiego" [60] była grana w Łodzi w kinie Urania. W Sfinksie w Warszawie film pokazano pierwszy raz dopiero w Pesach, które w 1939 roku przypadło 4 kwietnia. Wyświetlany na sześciu seansach dziennie film, utrzymał się w repertuarze tego kina do 15 maja. „Żydowskie” Apollo w Białymstoku grało List do matki chyba tylko jeden dzień - 5 kwietnia[61], a potem, w połowie miesiąca, przez dwanaście dni można go było oglądać w „chrześcijańskiej” Polonii. Był też wyświetlany w wileńskiej Muzie. Z zestawienia dat wynika, że ani Lucy i Misza Germanowie, ani Green z żoną nie uczestniczyli w warszawskiej premierze, bowiem pierwsi wypłynęli do Stanów Zjednoczonych z Hawru na „Île de France" 8 marca, natomiast Anette i Joseph Green z Cherbourga na "Queen Mary" 18 marca. Zapewne Green był w pełni świadomy, że dla jego firmy polski etap przygody z kinem zakończył się, toteż odstąpił ją Wekwajzerowi (wraz z zaległymi podatkami). Prawa do dystrybucji Listu do matki otrzymały: Continental Film oraz - na Polskę południową - Bezet-Film.

W ciągu trzech lat Green osiągnął wyjątkowo silną pozycję. Był producentem, współreżyserem, a także pomysłodawcą bądź współscenarzystą, czyli jednostkową siłą sprawczą wszystkich swoich produkcji, w których konsekwentnie podejmował tematykę żydowską. Był autorem swoich filmów w stopniu nieporównywalnym z żadnym innym twórcą polskiej branży kinematograficznej[62]. W połowie 1938 roku Green zakupił od Ireny Zarzyckiej prawa do ekranizacji Dzikuski[63]. Gdyby nie wybuch wojny, stałby się także producentem filmów polskojęzycznych.

Jeszcze przed premierą filmu Judel gra na skrzypcach stał się on przedmiotem ataku ze strony antysemitów. Czytelnik łódzkiego „Echa”, deklarujący się jako chrześcijanin, w artykule Nowy film „Jidl mitn fidl” to „chluba” polskiej produkcji. Kompromitacja X Muzy, pisał: „Polak jest za wygodny, a żyd jest sprytny i ostatecznie on stworzył krajową produkcję i wyzyskuje obecnie naszą bierność". I dalej:

Żargonowych i czysto żydowskich filmów wcale z zainteresowaniem nie oczekujemy, lecz wręcz przeciwnie, z ogromnym wstydem i zażenowaniem! [...] Arogancja doszła już do tego, że wcale nie fatygują się nad daniem polskiego tytułu, tylko w ogłoszeniu pół-stronnem walą oryginalny tytuł żargonowy i to w dodatku w polskiej gazecie[64].

Nie minęły nawet trzy lata, gdy produkowane w Warszawie filmy żydowskie ze względu na wysoką jakość były stawiane za wzór reżyserom polskim przez Józefa Relidzyńskiego, naczelnika Cen-

[60] „Ilustrowana Republika” 1939, nr 70, s. 12 (sobota, 11 marca 1939).

[61] „Dziennik Białostocki” 1939, nr 95, s. 6 (środa, 5 kwietnia 1939); A. Łapińska, Kina białostockie w okresie międzywojennym, [w:] Białystok w 8o-leciu, pod redakcją C. Kukli, Białystok 20oo, s. 128. [62] A. Helman, Autor, [w:] Słownik pojęć filmowych, t. III, pod red. A. Helman, Wrocław 1992.
[63] „Film” 1938, nr 30, s. 9. Pierwszy raz Dzikuska została przeniesiona na ekran w 1928 roku przez Henryka Szaro.

[64] B.W., Nowy film "Iidl mitn fidl” to „chluba” polskiej produkcji. Kompromitacja X Muzy, „Echo” 1936, nr 233, s. 5 (sobota, 22 sierpnia 1936). Pisownia oryginalna. 
tralnego Biura Filmowego, zajmującego się cenzurą w Ministerstwie Spraw Wewnętrznych. Na konferencji w MSW w sprawie produkcji krajowej, która odbyła się 24 lutego 1939 roku, Relidzyński mówił, że kręcone w Polsce filmy „w języku żydowskim, oddają rzeczywistość żydowską w świetle właściwym, tj. ciepłym”, a autor Komunikatu prasowego z tejże konferencji dodał, iż „należałoby sobie życzyć, aby filmy polskie tę rzeczywistość polską, co najmniej równie dobrze reprezentowały"[65].

Na ekrany amerykańskie List do matki wprowadzono 14 września 1939 roku. Reklamowany był błędnie jako ostatnia produkcja żydowska przedwrześniowej Polski[66] (w rzeczywistości był nią dramat Bezdomni [On a hejm] Aleksandra Martena), również mówiący o emigracji.

Julian Leigh, który zajmował się przygotowywaniem napisów angielskich do filmów jidyszowych, na zamówienie Sphinx Films Corp. - dystrybutora produkcji Greena w Stanach Zjednoczonych opracował także $A$ briwele der mamen (używano także angielskich tytułów: A Letter to Mother, A Message to Mother i The Eternal Song). Film został uznany za najlepszą produkcję żydowską, jaką tam wyświetlano[67], a także największy sukces kasowy w dziejach kina jidyszowego. Według Judith N. Goldberg, która oparła się na informacji Greena, Amerykańska Akademia Sztuki i Wiedzy Filmowej rozważała przyznanie filmowi nominacji do Oscara[68]. Hoberman neguje tę możliwość, przypominając - niezbyt precyzyjnie - że nagrody Akademii dla najlepszego filmu nieanglojęzycznego są przyznawane dopiero od 1956 roku[69]. Na ekrany amerykańskie List do matki wracał od czasu do czasu. W 1945 roku po pokazach w Jewish Community Center w Oakland, w miejscowej gazecie Theresa Loeb doceniła walory scenariusza i sugestywną grę, które jednak zostały według niej w znacznym stopniu obniżone z powodu słabości technicznej filmu[70].

Wiosną 1936 roku w Warszawie odbyła się premiera melodramatu Za grzechy w reżyserii Aleksandra Martena. Film ten powstał w szczególnych okolicznościach - był produkcją niejako okazjonalną,

Złoty wiek kina jidyszowego mającą na celu zatrudnienie artystów żydowskich, którzy zostali wyrzuceni bądź uciekli z Trzeciej Rzeszy[71]. Został przyjęty życzliwie przez widzów, choć nie wyróżniał się walorami artystycznymi, nie znalazł też kontynuatorów, toteż za początek złotego okresu kina żydowskiego uważany jest dzień premiery Judel gra na skrzypcach Greena, która

[65] Komunikat prasowy Związu Dziennikarzy i Publicystów Filmowych o konferencji w Ministerstwie Spraw Wewnętrznych $w$ sprawie tematyki filmowej krajowej produkcji, „Aktualności” 1939, nr 1, s. 9. Jest to o tyle paradoksalne, że owa konferencja miała wydźwięk wyraźnie antysemicki.

[66] Yiddish Stars in New Film, „The Pittsburgh

Press" 1939, nr 136, s. 13.
[67] Ibidem.

[68] J.N. Goldberg, op.cit., s. 110.

[69] J. Hoberman, op.cit., s. 297.

[70] Zob. T. Loeb, Skilled Gast Triumphs in Yiddish Film, „Oakland Tribune” 1945, nr 184, s. 12.

[71] N. Gross, op.cit., s. 63-66. 
nastąpiła pięć miesięcy później. Amerykański sukces tej komedii muzycznej sprowokował u Edgara G. Ulmera i Jacoba Ben-Amiego chęć nakręcenia ambitnego filmu artystycznego, który cieszyłby się jeszcze większą frekwencją niż produkcja Greena. Tak w 1937 roku powstały Zielone pola według Hirszbejna, wartościowy dramat, który jednak nie był oglądany tak chętnie jak Judel... Nawiasem mówiąc, to firma Greena dystrybuowała go w Polsce w 1938 roku. Wkrótce powstały następne filmy jidyszowe. W Polsce, oprócz produkcji samego Greena, także: Weseli biedacy, Ślubowanie, Dybuk i Bezdomni, a w Stanach Zjednoczonych, kolejne po Zielonych polach filmy Ulmera: Śpiewajacy kowal (Jankl der szmid / The Singing Blacksmith, 1938, współreżyseria Ben Zwi-Baratoff), Szkapa (Die kliacze / A Light Ahead, 1939, współreżyseria Henry Felt) i Amerykański szatchen (Amerikaner szatchn / American Matchmaker, 1940), a także: Syn kantora / Miasteczko Bełz (Dem chazns zundl / Cantor's Son, 1937) Sidneya M. Goldina i Ilyi Motyleffa oraz Kantor wileński (Der wilner sztot chazn / Ouverture to Glory, 1940) Maxa Nossecka. Złoty okres kina jidyszowego trwał niespełna trzy lata. Kres położyła mu druga wojna światowa.

We własnym teatrze

W drugiej połowie 1944 roku Green i Jacob Ben-Ami wynajęli The New Yiddish Art-Theatre na rogu Second Avenue i 12th Street. Green wyprodukował tam dwie sztuki, które, pod kierunkiem Ben-Amiego, wyreżyserował łodzianin Isaac Rothblum. Najpierw, 15 października, odbyła się premiera Cudu w getcie warszawskim (Der nes in ghetto) Halperna Lejwika. Pełna dramatyzmu epicka kronika trzydziestodniowej walki Żydów wiosną 1943 roku została wyprodukowana zaledwie osiemnaście miesięcy po powstaniu. Bojownicy reprezentują bardzo różne poglądy i przekonania polityczne, od komunistów po ortodoksów. Jednak na czas walki zapominają o dzielących ich różnicach. A najważniejszy staje się dla nich przekaz dla świata: „Trwamy!”. Główną rolę zagrał Jacob Ben-Ami, obok niego wystąpili między innymi Muriel Gruber, Dina Halpern, Isidor Cashier, Menachem Rubin, Isaac Rothblum i Abraham Teitelbaum, narrację w języku angielskim czytał Sam Jaffe. Inscenizacja ta była prezentowana także poza Nowym Jorkiem, między innymi w Chicago w kwietniu 1945 roku.

Natomiast 19 grudnia 1944 roku odbyła się premiera sztuki Dawida Bergelsona Będziemy żyli (Mir weln lebn). Bergelson (ur. 1884) W 1932 roku wrócił z Berlina, gdzie mieszkał kilkanaście lat, do Moskwy. W czasie drugiej wojny był działaczem Żydowskiego Komitetu Antyfaszystowskiego. Wraz z innymi członkami tego komitetu został zamordowany 12 sierpnia 1952 roku na Łubiance. Będziemy żyli była to pierwsza teatralna reakcja na Holokaust na Ukrainie. Bergelson przedstawił w niej losy Żydów z małego miasteczka, z których część rozpoczęła walkę partyzancką, niektórzy zostali zamordowani, inni trafili do obozów. Głównymi bohaterami są: kierownik laboratorium (Jacob Ben-Ami), jego ojciec (Isidore Cashier) i córka (Muriel Gruber). W sztuce wystąpili też między innymi Dina Halpern, Menachem 
Rubin i Abraham Teitelbaum. Zarówno Cud w getcie warszawskim, jak i Będziemy żyli odniosły znaczny sukces finansowy[72].

Po drugiej wojnie światowej Green nie wyprodukował już żadnego filmu. Świat, który chciał przedstawiać, przestał istnieć. Spośród współpracowników Greena zginęli: Dora Fakiel, Chana Lewin, Basia Liebgold, Maks Bryn, Symcha Fostel, Abraham Kurc, Samuel Landau, Jacek Rotmil, Ajzyk Samberg, prawdopodobnie też M.E. Wekwajzer[73], a o wielu innych brak pewnych wiadomości, na przykład ostatnie informacje na temat Leona Kaswinera pochodzą z 1941 roku. Tragedia Holokaustu dotknęła Greena także osobiście. Zamordowane zostały jego trzy siostry[74], a prawdopodobnie także matka.

Po zakończeniu wojny Green nadal mieszkał w Nowym Jorku i zajmował się dystrybucją swoich przedwojennych produkcji. Chaim Pevner napisał, że w Polsce Green stał się artystą, a Stany Zjednoczone uczyniły z niego obnośnego handlarza, który wszystkim wokół oferował własne filmy[75]. W 1956 roku kopia Judel gra na skrzypcach została odnowiona i uzupełniona kilkoma scenami z Mateczki, po czym całość zdubbingowano na język angielski. Stworzonemu w ten sposób filmowi Green nadał tytuł Zamki w niebie (Castles in the Sky). Pod koniec lat pięćdziesiątych planował powrót do kinematografii. Miał zamiar nakręcić muzyczną wersję Opuszczonego zakątka (Farworfn winkl) Hirszbejna z Moishe Oysherem w roli głównej, ale plany te przerwała śmierć aktora (27 listopada 1958 roku).

W październiku 1977 roku filmy Greena zostały pokazane na First New York Yiddish Film Festival. W Polsce po raz pierwszy twórczość Greena zaprezentowali w Krakowie w maju 1988 roku na Festiwalu Kultury Żydowskiej Krzysztof Gierat i Janusz Makuch.

W grudniu 1982 roku zmarła Anette, żona Greena. Wkrótce potem przeniósł się on do domu opieki w Great Neck na Long Island. Jego wypowiedzi na temat kina jidyszowego zostały włączone do filmów dokumentalnych Migdały i rodzynki (Almonds and Raisins, 1984, reż. David Elstein, Russ Karel) i Kino jidyszowe (The Yiddish Cinema, 1990, reż. Rich Pontius). Judel gra na skrzypcach doczekał się także wersji scenicznej, przerobiony na musical przez Isaiaha Sheffera. Premiera, w wykonaniu Jewish Theatre on Broadway w reżyserii Rana Avniego, odbyła się 24 października 1990 roku w Town Hall w Nowym Jorku; musical pokazano także w Los Angeles, Fort Lauderdale, Palm Beach i Bostonie. Filmy Greena były prezentowane na licznych festiwalach

[72] A. Pollock, Jacob Ben-Ami Offers „We Will Live” at Jewish Folk Theater, „The Brooklyn Daily Eagle”, nr ze środy 20 grudnia 1944, s. 8.

[73] „Mitteilungsblatt der Stadt Warschau / Dziennik Obwieszczeń Miasta Warszawy” 1941, nr 15, s. 2 (z 16 kwietnia 1941).

[74] Być może Ruchla była egzaminatorką (z rysunku technicznego) 29 sierpnia 1943 roku na zawodowym
Nowojorskie lata

kursie stolarstwa w getcie łódzkim. Zob. Kronika getta łódzkiego / Litzmannstadt getto 1941-1944, t. III: 1943, oprac. i red. nauk J. Baranowski [et al.], Łódź 2009, s. 444 .

[75] Ch. Pevner, Joseph Green, the Visionary of the Golden Age, [w:] When Joseph Met Molly. A Reader on Yiddish Film, red. S. Paskin, Nottingham 1999, s. 65. 
i przeglądach kina żydowskiego, natomiast on sam prawie został zapomniany. Po długiej chorobie zmarł w domu opieki w Great Neck 20 czerwca 1996 roku. W uroczystościach pogrzebowych uczestniczyły tylko trzy osoby, jedną z nich była Sharon Pucker Rivo z National Center for Jewish Film w Brandeis, instytucji, której celem jest kolekcjonowanie, restaurowanie i popularyzacja kina jidyszowego.

Akta miasta Łodzi, księgi ludności stałej z lat 1903-1931 (sygn. 10057, sygn. 10460); Spis ludności z lat 1916-1921, Archiwum Państwowe w Łodzi, sygn. 24628 aw., Kim jest Molly Picon?, „Film” 1936, nr 9

B.W., Nowy film "Jidl mitn fidl” to „chluba” polskiej produkcji. Kompromitacja X Muzy, „Echo”1936, nr 233

Błazen, „Prawda o Filmie” 1937, nr 7

Caplan D., Nomadic Chutzpah: The Vilna Troupe's Transnational Yiddish Theatre Paradigm, 1915-1935, „Theatre Survey” 2014, z. 3

"Chwila” 1933, nr 5134

„Chwila” 1933, nr 5135

„Chwila” 1934, nr 5347

Der najer jidiszer film „Jidl mitn fidl” (Nowy film jidyszowy „Judel gra na skrzypcach”), „Literarisze Bleter” 1936, nr 39

Don Bosco, „Kino” 1937, nr 10

„Dziennik Białostocki” 1939, nr 95

Edga., „Yiddle With His Fiddle” (Polish Made), „Variety” 1937, nr 4

„Expresss Wieczorny Ilustrowany” 1933, nr 327

„Film” 1936, nr 1

„Film” 1936, nr 13

„Film” 1936, nr 17

„Film” 1938, nr 30

„Film” 1939, nr 7

„Film” 1939, nr 9-10

Finkelstein J., W towarzystwie Eliszewy i Mali Picon (Korespondencja własna „Chwili”), „Chwila” 1931, nr 4544

Freedland M., Joseph Green. Yiddisher poppa, „The Guardian” (London), nr z 4 lipca 1996

Goldberg J.N., Laughter through Tears. The Yiddish Cinema, Rutherford, Madison, Teaneck, London, Toronto 1983

Goldman E.A., Visions, Images, and Dreams. Yiddish Film Past and Present, Ann Arbor 1983

Gross N., Film żydowski w Polsce, przeł. A. Ćwiakowska, Kraków 2002

Halo! Tu Ameryka. Ameryka o Polsce: „Love of A Kingdom” („Miłość lub Królestwo”); „Der Purymspieler”, „Prawda o Filmie” 1938, nr 1

Helman A., Autor, [w:] Słownik pojęć filmowych, t. III, pod redakcją A. Helman, Wrocław 1992

Hoberman J., Bridge of Light. Yiddish Film Between Two Worlds, Hanover, London 2010

Igel E., Film żydowski. „List do matki” - Kino Marysieńka, „Chwila” 1939, nr 7170

„Ilustrowana Republika” 1939, nr 70

Informator m. Łodzi z Kalendarzem na rok 1920. Spis firm handlowo-przemysłowych w Łodzi z podziałem na branże w porządku alfabetycznym, Łódź [1920]

J.B., La Colonie scolaire, „L'Univers Israélite” 1936, nr 33 
J. St., Śmiej się pajacu... Reportaż z atelier, „Kino” 1937, nr 33

K., Komisfilm - Jasna 24, „Wiem Wszystko” 1937, nr 8

Komunikat prasowy Zwiąku Dziennikarzy i Publicystów Filmowych o konferencji w Ministerstwie Spraw Wewnętrznych w sprawie tematyki filmowej krajowej produkcji, „Aktualności” 1939, nr 1

Korotkij W.M., Opieratory i reżissiery russkogo igrowogo kino 1897-1921. Biofilmograficzeskij sprawocznik, Moskva 2009

Krajewska H., Życie filmowe Łodzi w latach 1896-1939, Warszawa-Łódź 1992

Kronika getta łódzkiego / Litzmannstadt getto 1941-1944, t. III: 1943, opracowanie i redakcja naukowa: J. Baranowski et al., Łódź 2009

Leyko M., Teatr Icchoka Zandberga, [w:] Łódzkie sceny żydowskie. Studia i materiały, pod redakcją M. Leyko, Łódź 2000

Loeb T., Skilled Gast Triumphs in Yiddish Film, „Oakland Tribune” 1945, nr 184

Łapińska A., Kina białostockie w okresie międzywojennym, [w:] Bialystok w 80-leciu, pod redakcją C. Kukli, Białystok 2000

„Mitteilungsblatt der Stadt Warschau / Dziennik Obwieszczeń Miasta Warszawy” 1941, nr 15

M.K. [M. Kanfer], Morris Schwarz jako Towje Mleczarz, „Nowy Dziennik” 1935, nr 356

Moasi [M. Kanfer], Z ekranu: „Dybuk”, „Nowy Dziennik” 1937, nr 259

„Nasz Przegląd” 1935, nr 285

Ostrzeżenie przed kiczem filmowym, „Gazeta Polska” $1934 \mathrm{nr} 88$

Pevner Ch., Joseph Green, the Visionary of the Golden Age, [w:] When Joseph Met Molly. A Reader on Yiddish Film, red. S. Paskin, Nottingham 1999

Picon M., Fiddling in Old Kazmierz, „The New York Times” 1937, nr 10

Picon M. (i J.B. Grillo), Molly!, New York 1980

„Piętro wyżej” po żydowsku, „Film” 1938, nr 25

Podręczny rejestr handlowy, Łódź [1926]

Pollock A., Jacob Ben-Ami Offers „We Will Live” at Jewish Folk Theater, „The Brooklyn Daily Eagle", nr z 20 grudnia 1944

Riss H., Żydowscy artyści z Polski w Berlinie, przeł. Małgorzata Leyko, [w:] Teatr żydowski w Polsce, pod red. A. Kuligowskiej-Korzeniewskiej i M. Leyko, Łódź 1998

(r-s.), W drodze z Palestyny do Moskwy. Przy czarnej kawie z Mali Pikon i J. Kalichem, „Nasz Przegląd” 1933, nr 147

Szydłowska M., Z dziejów żydowskich widowisk rozrywkowych we Lwowie przed 1945, „Pamiętnik Teatralny” 2014, z. 1-2

Szydłowska M., Ze Lwowa w filmowy świat, „Przegląd Polski” (Nowy Jork) nr z 3 grudnia 2010

The American Film Institute Catalog. Within our Gates: Ethnicity in American Feature Films, 1911-1960, red. A. Gevinson, Berkeley 1997

„Wiadomości Filmowe” 1935, nr 12

Włodek R., Bezdomni. Motyw emigracji w filmach jidyszowych, [w:] Przestrzeń w kulturze wspólczesnej: literatura, teatr, film, red. D. Mazur i B. Morzyńska-Wrzosek, Bydgoszcz 2016

Włodek R., Na poczatku było „Le’chajim”. Bardzo krótka historia kina żydowskiego, Szczecin 2013

Włodek R., Wileńska opowieść, „Midrasz” 2011, nr 4

Yiddish Stars in New Film, „The Pittsburgh Press” 1939, nr 136

Zajiček E., Poza ekranem. Kinematografia polska 1918-1991, Warszawa 1992

Zdarzenia i wypadki ubiegłej doby, „Echo” 1933, nr 346 